\title{
Bound in the Spiral Dance: Haraway, Starhawk and Writing Lives in Feminist Community
}

Dr Joan Haran

Marie Skłodowska-Curie Global Fellow

School of Journalism, Media and Culture

Cardiff University

Bute Building, King Edward VII Avenue

Cardiff CF10 3NB

Wales

UK

Email: haranj@cardiff.ac.uk

Twitter: @Joan Haran, @imaginactivism

Keywords: Starhawk, Haraway, Spiral Dance,

Abstract: This article uses the figure of the Spiral Dance to draw out biographical, theoretical, and political similarities and points of friction between Haraway and Starhawk. It suggests that Haraway's assertion that she would rather be a cyborg than a goddess foreclosed possibilities in feminism that have taken decades to reconstruct.

This project has received funding from the European Union's Horizon 2020 research and innovation programme under the Marie Skłodowska-Curie Grant Agreement No. 661561 


\section{Bound in the Spiral Dance: Haraway, Starhawk and Writing Lives in Feminist Community}

"A cyborg is a cybernetic organism, a hybrid of machine and organism, a creature of social reality as well as a creation of fiction." (Haraway, "Cyborg Manifesto" 149)

"I have spoken of the Goddess as psychological symbol and also as manifest reality. She is both." (Starhawk Spiral Dance 107)

"The Children of Compost insist that we need to write stories and live lives for flourishing and for abundance, especially in the teeth of rampaging destruction and impoverization." (Haraway Staying With the Trouble 136).

\section{Introduction}

In this article I draw out interconnections in the lives and work of two important US feminist thinkers: Donna Haraway, a founding scholar of feminist cultural studies of technoscience, and Starhawk, a leading theorist of feminist spirituality and ecofeminism, an activist, and a trainer in permaculture and direct action. It may seem perverse to yoke them together because Haraway's association with theoretical sophistication and science studies appears to be antithetical to Starhawk's espousal of Witchcraft; Goddess religion that: "takes its teachings from nature". Yet the assumed gulf between them belies a great deal that they share, relies on reductive readings of their work, and reveals just how powerful, pervasive and persistent are the dualisms they have both worked to dismantle. More importantly, perhaps, I suggest that their modes of knowledge production complement each other. After all, although Haraway asserted that she would rather be a cyborg than a goddess, she first pointed out that "both are bound in the spiral dance"("Cyborg Manifesto" 181). Nonetheless, the significance of both spiral dance and goddess is often lost or misconstrued. I encourage feminists and others yearning for social and ecological justice - particularly those who define feminist theory more narrowly - to read Starhawk's oeuvre as attentively and generously as they have read Haraway's because of the resources that she offers for feminist praxis. For roughly four decades she, and other ecofeminists, have anticipated the call to action of Haraway's Children of Compost, but their work and lives have not been afforded the attention that Haraway rightly has.

\section{Bringing Starhawk and Haraway Together}

I am not alone in my desire to bring their work together. Others in ecofeminism, feminist spirituality and feminist theory and, crucially, at their intersection, have done the same (Klassen; Moore; Puig). Yet for many Starhawk and Haraway are imagined to stand for opposing poles in feminism. This assumed polarisation of emerges from a series of rhetorical moves in academic feminism that relegated feminist essentialism (attributed to radical and eco-feminists) to the 1970 s with putatively more sophisticated post-structuralist feminist theory ascendant in the 1980s and 1990s; moves which manifested a dualism that both 
ecofeminists and Haraway critiqued (Moore 216-230). Through this lens, Haraway was assigned to the theoretically sophisticated camp, Starhawk consigned to the camp of unsophisticated essentialism. This seems deeply ironic given Haraway's devout wish that people feel permitted to take risks in their thinking, and Starhawk's self-conscious embrace of a "woo woo" subject position that allows her to "think about anything" (Starhawk, Earth Path 27). Haraway's "Cyborg Manifesto" was understood by many to construct a boundary between these camps despite her own stated intention to hold feminist science studies and ecofeminism together ${ }^{1}$. Some communities of practice made a judgement about which side of the divide spiritually inclined feminists or ecofeminists belonged and did not revisit that judgement. For many others, of course - in some cases due to the success of this boundary management - one writer is a familiar name and the other unknown. So why bring them together?

Both have produced a body of work and themselves embody ways of being that provide hope and inspiration to those who yearn to inhabit a just and anti-oppressive world; one in which technoscience serves the needs of people and planet, rather than damaging both through extractive practices that benefit a few. In "Situated Knowledges" 2 , Haraway identifies commitments that I argue Starhawk shares: "a critical practice for recognizing our own 'semiotic technologies' for making meanings, and a no-nonsense commitment to faithful accounts of a 'real' world, one that can be partially shared and friendly to earth-wide projects of finite freedom, adequate material abundance, modest meaning in suffering, and limited happiness" (187). Their self-conscious deployment of 'semiotic technologies' may differ, but both are highly attuned to the work of making meaning in pursuit of the earth-wide projects Haraway identifies.

The title of Haraway's most recent book, Staying With the Trouble, gives a further clue to the resonances across their work. Both women have repeatedly reworked their arguments over time. This iterative re-engagement with their respective philosophical and political analyses is in service to their shared commitment to making a difference and includes both efforts to better elucidate earlier work and to change their positions when they consider it necessary. For example, Starhawk refutes accusation of essentialism, but acknowledges that when writing the first version of The Spiral Dance she was still influenced by Jungian formulations: "In the 1989 introduction, I wrote extensively about my shift away from a polarized view of the world as a dance of "female" and "male" qualities and energies, and towards a much more complex and inclusive view of gender and energy. That shift continues to deepen as I grow older, and it is still the major change I would make in this book." (3) This reworking is opaque to those who approach their work through secondary - particularly

\footnotetext{
1 "Imaginactivism: A Public Conversation with Donna Haraway and Starhawk: Magic, Figuration \& Speculative Fiction as Calls to Action", Wednesday, October 18, 2017, 6 - 8 pm, University of California at Santa Cruz

${ }^{2}$ An essay which Haraway suggests is the sister-paper to the manifesto (2016b: 207)
} 
taxonomizing texts - or through readings of a single instance of their work. I want to clarify how reworking and revision is bound up with their respective biographies, biographies that are resolutely political. Although I focus my argument through one iconic text by each writer, I also draw on their other works and on a public conversation between the two that I convened in October 2017, as part of my Imaginactivism research. Although drawing from the accounts they give of themselves in their texts, I use the term biography rather than autobiography for the following reasons. The biographies I draw out from the texts are resolutely relational. Both Haraway and Starhawk write themselves in relation to communities, collaborators, movements and political history. Further, this is my weaving together of threads of story drawn from texts that set out to offer their readers accounts of the structured and patterned nature of social and political orders, collective spiritual and / or political strategies and techniques to intervene. The contestation of heroic individualized narratives forms part of their common approach, and indeed my own weaving is influenced by conversations I've had with friends and colleagues bound in the spiral dance with Haraway and Starhawk. I use the figure of the spiral dance to render explicit what Haraway gestured towards in the final sentence of the manifesto - that it is the relational working-out and working-through of shared problems or commitments as each feminist or feminist collective turns and returns to them that makes feminism lively and vibrant. Despite Haraway's own appreciation in the manifesto of Katie King and Chela Sandoval's refusal of "a logic of taxonomisation"(157), and her argument for taking pleasure in the confusion of boundaries, the essay ironically reiterated one of the problems she herself identified, that: "History and polyvocality disappear into political taxonomies that try to establish genealogies" (160). By turning to biography I hope to tease out for other readers the dance in which Starhawk and Haraway are bound, one of knowledge creation in the pursuit of more livable worlds for all.

\section{Brief biographical sketch/Biographical commonalities}

Neither writer has yet featured in a full-length biography but for myself, and I'm sure for many others, a huge part of the pleasure of reading the work of both Starhawk and Haraway is the impression we form of knowing them - and wanting to know them - through biographical fragments woven through their work. Mixing metaphors, we are caught up in the cat's cradle of stories and footnotes that refer to their personal and professional lives, and trace their networks. This practice is testimony to the ways that they both invite their readers into an imagined community, binding them into the spiral dance of feminism. A more concerted investigation reveals key commonalities that make it more striking that until October 2017 they had never met nor discussed their work with each other. Perhaps this is telling about some of the faultlines in feminism. My abiding sense that they have both dedicated their lives to a common project of worlding, albeit with points of friction was the reason that I worked to bring them together at the University of Santa Cruz. They share material as well as political terrain. Born seven years apart, they were both observant and scholarly practitioners of their given faiths until they entered young womanhood - Starhawk of Judaism, and Haraway of Roman Catholicism. Their subsequent questioning of their 
respective religions sent them down different paths, with Starhawk playing a significant part in the spread of Goddess or earth-based spirituality and Haraway repudiating religion even as she values some of what it makes possible, and indeed credits Catholicism for sensitising her to her material semiotic approach to knowledge-making. The diligent quality of their early observance also foreshadowed their intense commitment to their work, to seeking and making meaning, and their fascination with story-telling.

Both have spent roughly four decades in Northern California in the greater Bay Area in queer multispecies households ${ }^{3}$. Starhawk shares homes in San Francisco and Sonoma County -- a Victorian townhouse and a small ranch - with her husband and friends / co-workers, while Haraway lives with her husband in Santa Cruz and, with landmates, also in Sonoma. Haraway helped build the house in Sonoma County where she has done the majority of her writing since moving to UC Santa Cruz, while Starhawk has co-created a permaculture ranch in Sonoma with a variety of collaborators. Both have international reputations. Haraway's writing and teaching have been authorised by her position as a tenured academic until her retirement in 2010, while Starhawk has chosen to work largely as an independent author, although her second book Dreaming the Dark was also her Master's Thesis in the Feminist Therapy Program at Antioch University West. Re-turning to the two key texts which are iconic for their respective author's reputation, I point to how the "Cyborg Manifesto" gestures to its own entanglement in the Spiral Dance, I describe the material practice of spiral dancing and through reference to The Spiral Dance I begin to demonstrate the ways in which Starhawk's work complements Haraway's. I also draw out some of the sticking points that activate Haraway's choice of the cyborg over the goddess.

\section{Reading The Spiral Dance through "A Cyborg Manifesto"}

Haraway introduced the spiral dance - a ritual practice in earth-based spirituality and nonviolent direct action movements - as an additional if under-explicated figure in the manifesto that introduced the cyborg. If an academic essay could be accounted a "best seller" the "Cyborg Manifesto" would certainly have achieved that accolade ${ }^{4}$. It is a wide-ranging treatise in which Haraway is tackling, as the essay's subtitle makes clear "Science,

Technology and Socialist-Feminism in the Twentieth Century". The manifesto is too rich and complex to summarise meaningfully, but I will draw out just a few points that are key for thinking Haraway with Starhawk. The manifesto, Haraway argues, is predicated on "three crucial boundary breakdowns": between human and animal; between organism and machine;

\footnotetext{
${ }^{3}$ Both document queer and multispecies desire and kin-making that defies and exceeds heteronormativity and human exceptionalism over the course of their work..

${ }^{4}$ Because of its multiple sites of publication it is impossible to quantify the number of readers who have "bought" or read the text, but more than thirty years since its first publication it continues to be taught in universities all around the world. Apart from its initial journal publication, it has been re-printed in three books authored by Haraway: Simians, Cyborgs and Women (1991), The Haraway Reader (2004) and Manifestly Haraway (2016) (with Cary Wolfe), as well as many other thematic essay collections edited by others.
} 
between physical and non-physical. Its concluding paragraph restates "two crucial arguments": that "the production of universal, totalizing theory is a major mistake that misses most of reality" and that "taking responsibility for the social relations of science and technology means refusing an anti-science metaphysics, a demonology of technology" (181). These arguments are woven through a discussion of faultlines in the identity/ties of "women" and "feminists"; a critical history of the present which maps "a movement from an organic, industrial society to a polymorphous, information system"; and the creation of "a myth of political identity" that engages with cyborgs in two key modes - tracing cyborg identity first through "women of colour" feminism and then through feminist science fiction.

\section{Spiral Dancing}

Haraway concludes the manifesto with a figurative reference to "the spiral dance" (181), but this follows her mention of a specific material iteration of the dance in her hypothesis that: "Ironically, it might be the unnatural cyborg women making chips in Asia and spiral dancing* in Santa Rita jail whose constructed unities will guide effective oppositional strategies." (154). Starhawk led the spiral dancing in Santa Rita jail with her affinity group, Matrix, following their arrests for protesting at the Lawrence Livermore Labs. ${ }^{5}$ Haraway identifies the spiral dance as "a practice at once both spiritual and political", clearly signalling their entanglement; a breakdown in clean distinctions indeed. The Spiral Dance is an embodied instantiation of the string figures about which Haraway writes so prolifically and persuasively. It can be understood as a technology used for creating community and raising energy to be directed towards spiritual or political ends, depending on where it is performed. Starhawk, of course, refuses the separation of spiritual and political. Dancing the spiral, one grasps hands only with one's immediate neighbours, but when the dance is led skilfully one passes every other dancer in the spiral - hundreds of them in the large Halloween rituals - face to face and makes deliberate eye contact with them, acknowledging each other's presence and committing to the intention that is set before the dance. The choreography of the spiral dance is both an enactment of and a lively metaphor for the work of feminist knowledge-- and movement-building which the two women have done for over forty years. It metaphorically evokes their practices of returning to and reworking their respective writing.

\section{Spiralling Through Starhawk's Work}

Like the "Cyborg Manifesto", The Spiral Dance is a bestseller. ${ }^{6}$ Starhawk wrote new introductions and notes updating her thinking in both tenth and twentieth anniversary editions $(1989,1999)$. By documenting the way that Starhawk's thinking changes through lessons

\footnotetext{
${ }^{5}$ The Reclaiming community of San Francisco has held a Spiral Dance for Halloween/Samhain annually since 1979. The first of these large public rituals was organised by Starhawk and friends in part to celebrate the publication of The Spiral Dance.

${ }^{6}$ Amazon.com currently (14 November 2017) lists it as the number 1 best seller in Gender Studies. Over one hundred thousand copies were sold before its second edition was produced.
} 
learnt through participation in movements including feminism, the book enriches the partial, historically situated mapping of US feminism that Haraway sketches in the manifesto. The Spiral Dance is a hybrid work of "history", politics and instruction in ritual which introduces "Witchcraft as Goddess Religion": "Witchcraft takes its teachings from nature, and reads inspiration in the movements of the sun, moon, and stars, the flight of birds, the slow growth of trees, and the cycles of the seasons." (27). The book's stress on imagination and creativity and even many of the techniques described seem potentially reconcilable with Haraway's cyborg vision, but the chapter which includes instructions for making spells and charms is much more challenging. Starhawk herself points out that even the most confirmed sceptic may be prepared to acknowledge that spells work on a psychological level, but that "spells can also influence the external world" is "more difficult to accept" (139). Her pragmatic assertion that "No magic spell is going to bring results unless channels are open in the material world. A job spell is useless unless you go out and look for a job." (140) does little to dispel the sense that Starhawk has pushed her creative work with myth and metaphor and her instruction in technologies of the self beyond a credible limit, for those who are interested in holding her work in productive tension with Haraway's. However, if we recast (pun intended) spells as speculative fiction, perhaps the chasm is not so great. The Spiral Dance ends with a piece of speculative fiction; an early draft fragment of Starhawk's 1993 novel The Fifth Sacred Thing. It portrays a future San Francisco in which pagan ritual is commonplace. The elders in this future have discussed discontinuing one of their ritual practices - that of seeking out and gathering up trash - because in this future there is no waste; everything is made to be used carefully. This vision is particularly pertinent to the exploration of the core commitments that underpin both Starhawk and Haraway's work. The inhabitants of this future city appear to enjoy "finite freedom, adequate material abundance, modest meaning in suffering, and limited happiness":

\footnotetext{
"They pour libations and give thanks - especially the very old ones, who remember when it was different.

'I am thankful that in this city, no one goes hungry.'

'I am thankful that in this city, no one is left to die alone.'

'I give thanks that I can walk the dark streets without fearing violence.'

'I give thanks that the air is clean, that life has returned to the waters of the bay, that we are at peace.'

'I give thanks that everyone has work to do.' (228)
}

\section{Entanglement Through Reiteration}

Of course, there are important differences between The Spiral Dance and "A Cyborg Manifesto", the most obvious being that one is a book-length work of "poetic thealogy" addressed to readers interested in exploring feminist earth-based spirituality and one a polemical essay explicitly addressed to an academic readership about transformations in the United States' scientific culture and political landscape and the need for feminist scholarship 
on these changes. But both arise from the way in which their authors' lives and ways of knowing and being have been transformed by feminism, and focus on strategies for resisting domination. The book's first publication predated the Manifesto's by six years; it was conceived in the Carter era and written before the AIDS epidemic. The Manifesto responded - at least in part - to challenges posed by the Reagan administration and juxtaposes "Immunology, AIDS" with "Microbiology, tuberculosis" in Haraway's "chart of transitions from the comfortable old hierarchical dominations to the scary new networks I have called the informatics of domination" (161). However, the repeated publication of new editions of each places them in odd temporal relation to each other, with repeated opportunities for their authors to retheorize their arguments based on their life experiences in turns and re-turns of the spiral.

In a book-length work there is a great deal more space to include biographic material, but Haraway's practice of re-visiting her work in response to multiple ongoing conversations resonates with the accounts of writing process and community-building that Starhawk weaves through her longer intervention, even as it requires more teasing out. One explicit re-visiting is in The Companion Species Manifesto (2003) where Haraway remarks: "I appropriated cyborgs to do feminist work in Reagan's Star Wars times of the mid-1980s. By the end of the millennium, cyborgs could no longer do the work of a proper herding dog to gather up the threads need for critical enquiry" (4) and "I have come to see cyborgs as junior siblings in the much bigger, queer family of companion species" (11). In this later work, her focus is much more on the breached boundary between human and non-human animals than the human / machine boundary and this focus on biological organisms makes similarities in the two women's pursuit of ecological justice more apparent. This point is underscored firmly in Haraway's speculative fiction "The Camille Stories" where she puts the words of a Starhawk song in the mouths of the Children of Compost; multispecies communities responsible for healing ruined places to make a newly habitable world (Haraway Trouble 166). In comparing their speculative fictions, it is worth noting that Haraway's protagonists are represented as being much earlier in the project of remediation. We might imagine them to be at an earlier movement in the spiral dance, or wonder why Starhawk didn't revise her speculations in the light of political and technological changes which took place in the twenty years since her book's first publication. However, both portray protagonists actively engaged in worldmaking, and the next section explores the authors' own worldmaking practices.

\section{Convergence and Affinity}

In their October 2017 public conversation at the University of Santa Cruz, I asked Starhawk and Haraway to begin by discussing their anti-nuclear activism in the 1980s. Starhawk explained that her involvement with the Livermore Action Group grew out of her participation in blockading Diablo Canyon to prevent a nuclear power plant from going online, which was a practical expression of her spirituality. She found the experience personally transformative, and the principles of organising around non-violence, nonhierarchy and participation to be congruent with her Goddess spirituality. Her participation in 
Matrix, an affinity group made up of witches, was highly influential on the subsequent development of the Reclaiming spiritual network. Responding, Haraway who participated in LAG actions in the UC Santa Cruz affinity group Surrogate Others, said that she had been inspired to do so by Starhawk's activism, taking part in later actions at the Lawrence Livermore Weapons Laboratory and the Nevada Test Site. ${ }^{7}$ She stressed that although she remained allergic to the language of the sacred, she recognised that her affirmation of "mortality and finitude", and "that the living and dying and flourishing with each other is worth living and dying for" fundamentally converges with what Starhawk would call the sacred.

Considering both her early devotion to Catholicism and her love of word play it is notable that Haraway feels unable to reclaim or re-vision the language of the sacred, whereas Starhawk asks: "Can we bend the meanings of the words back? Can we make "religion" mean "re-linking:? And can we make "spirituality" refer to the human spirit?" (215). It would be a mistake to reduce this to anthropocentrism, because in co-creating feminist spirituality Starhawk was focused on its potential to link people with each other and the world, and to "collectively create a culture of life". Further, she emphasized the importance of fostering diversity in the women's movement and argued for "the need to create a religion of heretics, who refuse to toe any ideological lines or give their allegiance to any doctrines of exclusivity." (219). The resonance of this argument with Haraway's "ironic political myth [which] is faithful to feminism, socialism and materialism. Perhaps more faithful as blasphemy is faithful, than as reverent worship and identification" (Haraway "Cyborg Manifesto" 149) seems undeniable. Starhawk refutes false conflicts between religion and science, because "the Goddess is manifest in the physical world, and the more we understand its workings, the better we know Her." (Spiral Dance 219) Of course, feminists and others who reject spirituality may be unmoved by Starhawk's desire "to see the Goddess religion of the future be firmly grounded in science, in what we can observe in the physical world" (220), but to assume that she espouses the anti-science metaphysics that Haraway insists we must refuse is clearly wide of the mark. Starhawk's resistance to the building of nuclear power plants is rooted in a historically-informed ethical and political opposition to specific harms, which resonates strongly with Haraway's approach, so her 'erasure' from the manifesto is troubling.

\section{Writing Community}

In the 1991 version of the "Cyborg Manifesto", the first - very extensive - footnote comprises Haraway's acknowledgments of the essay's genealogy; an extensive assemblage of financial and intellectual support. ${ }^{8}$ When taking such pains to acknowledge her debts, including the

\footnotetext{
${ }^{8}$ Particular attention is drawn to three graduate students in the History of Consciousness Department: Zoe Sofoulis, Katie King and Chela Sandoval whose work is referenced throughout the manifesto.
} 
claim that the paper "feels collectively authored more than most" (243), it is striking that the manifesto is often referred to as if the work of an individual(ist) genius. Further, although Haraway must have been aware that Starhawk had authored The Spiral Dance, she doesn't refer to her by name in the essay. It is tempting to speculate whether this omission was a deliberate citational decision.

Elsewhere in the Manifesto we can infer other senses of Haraway's biographical commitments. However, unless we read later work, e.g. "The Promises of Monsters" we don't learn she was a member of the affinity group "Surrogate Others" which "enacted a cyborgian emergence from the constructed body of a large, non-heterosexual desert worm" at the nuclear weapons testing facility in Nevada ("Cyborg Manifesto" n245). The spiralling quality of Haraway's reworking of the manifesto, and the personal and intellectual (of course they are inseparable) experiences which inform these reworkings can be traced through footnotes and through references in the work of her friends and colleagues. From these one can deduce that Sturgeon was a graduate student working with Haraway, Epstein a colleague at UCSC, and infer that Haraway's claim that the Surrogate Others were able "to participate as fully committed, if semiotically unruly, eco-feminists" in the 1987 Mother's and Others' Day action has been worked through in conversation with Sturgeon and Epstein ("Promises of Monsters" 97). Haraway's suggestion that there are "more grounds for hope in focusing on the contradictory effects of politics" braids together what we might call a utopian sensibility with historical consciousness and a recognition of contingency. But we can also appreciate that the quirky humour that both Haraway and Starhawk display was shared with a much larger creative movement - those dissidents that give Haraway hope including "the Livermore Action Group", and "the witch-weavings of the displaced and so unnatural Greenham women” (Haraway "Cyborg Manifesto" 153).

\section{Acknowledging Accountability}

In her books" "Acknowledgments", Haraway performs accountability to the intellectual and other communities that have enabled her work. From her first book, Primate Visions, she began a practice, continued throughout her work, of citing the doctoral students with whom she has worked most closely. She writes: "a faculty member is privileged to read papers and take part in conversations that fundamentally change one's way of seeing. This is a delicate, multidirectional, and collective process." (vii) This reference to the choreography of intellectual exchange evokes the figure of the spiral dance in which she, Starhawk and their respective interlocutors are bound. Primate Vision also marks the first of many acknowledgments to "Rusten Hogness and Jaye Miller", members of her "households in Honolulu, Baltimore, Santa Cruz, and Healdsburg who especially "sustain (her) sense of possibility in the human regions of the primate order" (viii). Of course, the work of an Acknowledgments sections is to recognise intellectual debts and debts of friendship, but Haraway's approach is particularly comprehensive, providing readers with a vivid insight into the lively networks that sustain her scholarship. 
As an author with a comparably singular reputation, Starhawk is also careful to express her gratitude to the communities from which her work springs. The Spiral Dance (1999) features thanks and acknowledgements from each successive edition. We learn that Starhawk has had ongoing love and support from her natal family, several covens, two husbands and her collective household. She names those with whom she has co-created new rituals, taught, written, and organized, and explicitly states that their arguments and conflicts, jokes and discussions "form the matrix of community from which my own changes have been born."

(ix) Like Haraway, she reveals a distinctly collaborative practice for knowledge-making and a supportive community of friends and lovers; a pagan networked community rather than an academic one 9 . Both their writing practices and their daily lives are deeply bound in the spiral dance of anti-oppressive, anti-hierarchical and participatory communities organised around feminism. The accountability they perform to the subjects of their acknowledgements is also evident in the ways that they draw their readers' attention to shifts in their thinking.

\section{Writing the Goddess}

As already mentioned Starhawk has been creative with her revisions of The Spiral Dance, producing new introductions for both tenth and twentieth anniversary editions and two distinct sets of notes on the chapters, signalled in the body of the text by single and double asterisks. The new content spirals around the original. In the tenth anniversary introduction she writes about the experiences and contingencies that led to her writing the book in the first place: "teaching a class in Witchcraft ... for our anthropology class" (14); becoming deeply involved with the women's movement; participating in the thriving Pagan community in the Bay Area. Whereas Haraway repeatedly expresses her love and passion for the theory and practice of Biology, and the way in which this attachment is important to her work, Starhawk repeatedly refers to her own embodied experience in relation to "nature", and her sense of lively, erotic connection with the world. Although Starhawk uses the language of "nature" it is evident from her work that this is not some unnuanced reification. As early as the first edition of The Spiral Dance she argued for a more interconnected understanding of humans' relationship to the earth and the other species with which it is shared; critiquing extractive relationships that have led to severe pollution and ecological destruction. Her argument that the "model of the Goddess who is immanent in nature, fosters respect for the sacredness of all living things" is read by some as undercutting this analysis, but this spirituality is constructed to encourage and support a way of pursuing ecological balance (34-5).

In 1989 Starhawk shared the urgency that informed Haraway's "Cyborg Manifesto", and a very similar analysis to Haraway's sketch of the informatics of domination:

\footnotetext{
${ }^{9}$ It is important to note also that the academy is present in the list of thanks; Carol Christ who introduced Starhawk to her editor and publisher holds a PhD from Yale and taught in several US universities.
} 
over the last decade, as the gap between rich and poor widened, as our nuclear arsenals were rebuilt, and the homeless began to die in the streets and the jobless to crowd the bread lines, as the United States moved into covert and overt wars in Latin America, and the AIDS virus spread while legislators sat on funds for education and treatment, as the environment deteriorated, the national debt quadrupled, and the hole in the ozone layer grew ominously, a more active political engagement seemed called for. (18).

She describes how the Reclaiming collective's participation in nonviolent direct action led them to bring lessons learnt in "empowerment, participatory organization, and consensus process" into the way they "planned, taught, and created ritual" (5). That "Goddess worship" comprises collective empowerment, the work of social transformation and regenerating a damaged planet again suggests that the Goddess might be cyborg herself, not simply bound within the same spiral dance.

Moroever, Starhawk notes that her "current passion is to integrate more closely the worship of nature with knowledge that comes from the observation of nature, and to infuse science, ecological design, and environmental activism with the deep connectedness that comes from acknowledging the sacred." (9). In The Earth Path and in Earth Activist Training courses in "permaculture design with a grounding in spirit and a focus on organizing and activism" that she has been co-teaching internationally since 2001 , she has shared that passion, cultivating what Donna Haraway, following Anna Tsing, would call the arts of living on a damaged planet.

\section{What was lost in the turn from the goddess?}

Haraway's sign-off at the conclusion of the "Cyborg Manifesto"; "I would rather be a cyborg than a goddess" (181) has provoked a range of responses. I'm interested in what is lost by refuting the Goddess. What possibilities for coalition or collaboration were lost when Haraway did not recognise, was unaware of, or chose not to foreground the kinship of the cyborg and Starhawk's version of the goddess in The Spiral Dance? What possibilities were foreclosed upon by those taking up the mantle of cyborg feminism? Some years ago I wrote that this conclusion posed "a foundational dichotomy that seems at cross purposes with the boundary transgressing impulse of her overall theoretical project" (Haran 284). Thom van Dooren contends that this remark "does not represent a dismissal of Paganism... but is rather both a commitment to work in solidarity with Paganism ... and a challenge to these traditions to consider the role of potential oppressive dualisms and categories ... in their thought and action" (van Dooren 55-6). van Dooren's reading is probably closer than my own to Haraway's intentions. In "A Kinship of Feminist Figurations" she advocates for "an elsewhere born out of the hard (and sometimes joyful) work of getting on together in a kin group that includes cyborgs and goddesses working for earthly survival" (3). However, I agree with Isabelle Stengers that: "[Haraway] did not take the time and the needed care to anticipate and thwart the enthusiastic adhesion of her academic milieu, a milieu she 
authorised to snigger and promote a heroic adhesion to the cyborg as an (academic) weapon against those who still believe in ... (pick your choice)' (Stengers 51-2). Despite Haraway's urge to refute totalizing theory, the manifesto in effect theorised the cyborg successor to socialist-feminism by distinguishing it hierarchically from radical feminism and "the related positions of ecofeminism and feminist paganism" which were faulted for their insistence on the organic and over-restriction of "what we allow as a friendly body and political language." (174)

In the entire manifesto, Haraway names the Spiral Dance just three times - once in a footnote - and the Goddess three times - once in the conglomerate 'mad-goddess-planettrickster-old woman-technological device' (179); she uses the term cyborg(s) forty-nine times. Whilst the cyborg figure has been extremely generative, I am curious about whether, had she given a little more attention to Goddess feminists and the ecofeminist activisms that they were practicing, other feminists might also have attended to the nuance and creativity in the knowledge that they produced rather than diagnosing essentialism. As Niamh Moore points out Haraway "has sometimes explicitly taken up the work of eco/feminists and has rejected simplistic readings that reduce eco/feminism to essentialism" (Moore 69), but readers who don't read across her work and who adhere to the cyborg lo(o)se "the tension of holding incompatible things together because both or all are necessary and true" "Cyborg Manifesto" 148). I submit that if more feminists had read Starhawk's account of the immanent Goddess more carefully, recognising her attention to the empirical as well as her feminist materialist politics a fruitful entanglement with Haraway's material-semiotics might have offered a way to pursue knowledge about the liveliness of the world nearly two decades before the efflorescence of feminist new materialisms.

Haraway argues: "I like layered meanings, and I like to write a sentence in such a way that by the time you get to the end of it - it has at some level questioned itself. There are ways of blocking the closure of a sentence, of a whole piece, so that it becomes hard to fix its meanings. I like that, and I am committed politically and epistemologically to stylistic work that makes it relatively harder to fix the bottom line." (More Things Going On 333). While I appreciate this rhetorical strategy, it was not entirely successful with the manifesto. Feminists and others enthralled by the cyborg focused on the boundary breakdown between human and machine at the cost of the other breakdowns Haraway identified, and in the process felt permission to dismiss ecofeminism and feminist paganism.

\section{Conclusion: ReTurning to the Goddess}

In Haraway's self-designated "speculative fabulation", "The Camille Stories: Children of the Compost" she ventriloquizes: "The Children of Compost insist that we need to write stories and live lives for flourishing and for abundance, especially in the teeth of rampaging destruction and impoverization." (36). Some might argue that that is what Starhawk has been doing with her entangled spiritualpolitical writingpracticing all along. For readers who have 
long recognized the kinship of the goddess and the cyborg, it is affirming that the Speakers for the Dead in the future communities whose story Haraway fabulates sing the words of a Starhawk poem as a hymn "in ceremonies for resurgence attuned to the wounded earth" ("Camille Stories" n228). The final couplet reads: "Keen and mourn / for the dismembering of the world" (Staying With the Trouble 166). In this future Haraway marks the importance of ritual and recognises that "Starhawk's song insists on the importance of feeling pain as an active historical sensibility, as a practice in what Stengers calls an ecology of practices." ("Camille Stories" n228). By drawing on Starhawk's poetic knowledge and building it into an imagined ritual in the future of earth remediating practices that she imagines in "The Camille Stories", Haraway demonstrates the common cause that they have both shared for many decades and winds the cyborg and the goddess into much closer proximity in the Spiral Dance.

\section{References}

Epstein, Barbara, Political Protest and Cultural Revolution: Nonviolent Direct Action in the 1970s and 1980s, Berkeley and Los Angeles: University of California Press, 1993. Print Sturgeon, Noël Ecofeminist Natures: Race, Gender, Feminist Theory and Political Action New York and London: Routledge, 1997. Print.

Haran, Joan (2003) Re-visioning Feminist Futures: Literature as Social Theory

Haraway, Donna J. "A Cyborg Manifesto: Science, Technology, and Socialist-Feminism in the Late Twentieth Century", in Simians, Cyborgs and Women: The Reinvention of Nature, London: Free Association Books, 1991a. Print.

— "Situated Knowledges: The Science Question in Feminism and the

Privilege of Partial Perspective" Simians, Cyborgs and Women, London: Free

Association Books, 1991b. Print.

— "Reading Buchi Emecheta: Contests for 'Women's Experience' in Women's Studies"

Simians, Cyborgs and Women, London: Free Association Books, 1991c. Print.

- Primate Visions, London and New York: Verso, 1992 (1989)

- The Companion Species Manifesto, Chicago: Prickly Paradigm Press, 2003. Print.

— "The Promises of Monsters: A Regenerative Politics for Inappropriate/d Others", The

Haraway Reader, New York and London: Routledge, 2004. 63-124. Print.

- "Cyborgs, Coyotes, And Dogs: A Kinship of Feminist Figurations", The Haraway Reader, New York and London: Routledge, 2004, 321-332. Print.

- "There Are Always More Things Going On Than You Thought! Methodologies as

Thinking Technologies", The Haraway Reader, New York and London: Routledge, 2004, 333-342. Print.

— Staying with the Trouble, Durham and London: Duke University Press, 2016a. Print.

- Manifestly Haraway, London and New York: Verso, 2016b. Print.

Klassen, Chris, Storied Selves: Shaping Identity in Feminist Witchcraft, Lanham: Lexington Books, 2008. Print.

Moore, Niamh, The Changing Nature of Eco/Feminism: Telling Stories from Clayoquot

Sound, Vancouver: UBC Press, 2015. Print.

Puig de la Bellacasa, Maria, "Ethical Doings in Naturecultures." Ethics, Place and

Environment 13.2 (2010): 151-169. Print

Starhawk, Truth or Dare, San Francisco: Harper and Row, 1990. Print. 
- The Fifth Sacred Thing, New York: Bantam Books, 1993. Print.

- The Spiral Dance (Special $20^{\text {th }}$ Anniversary Edition), San Francisco: Harper and Row, 1999. Print.

- The Earth Path, New York: HarperSanFrancisco, 2004. Print.

-The Empowerment Manual, Gabriola Island, BC: New Society Publishers, 2011. Print. Stengers, Isabelle, "Experimenting With Refrains: Subjectivity and the Challenge of Escaping Modern Dualism", Subjectivity 22 (2008): 38-59. Print.

van Dooren, Thom, "I Would Rather Be a God/dess Than a Cyborg' A Pagan Encounter with Donna Haraway", Pomegranate 7.1 (2005): 42-58. Print.

Word count: 6326 not counting cover page 